\title{
Prospective Teachers' Representations for Teaching Note Values: An Analysis in the Context of Mathematics and Music
}

\author{
İlhan Özgül ${ }^{1}$, Lütfi İncikab1 ${ }^{1}$ \\ ${ }^{1}$ Kastamonu University Education Faculty, Turkey \\ Correspondence: İlhan Özgül, Kastamonu University Education Faculty Department of Fine Arts Education, \\ Kastamonu, Turkey.
}

Received: September 17, 2017

Accepted: October 24, $2017 \quad$ Online Published: October 25, 2017

doi:10.11114/jets.v5i11.2654

URL: https://doi.org/10.11114/jets.v5i11.2654

\begin{abstract}
In this study, the representations preferred by prospective teachers in the teaching of note values were determined and the accuracy of these representations was analyzed in the context of mathematics and music. The case study, one of the qualitative research designs, was used in the study. Study group of the research consisted of 113 pre-school teachers. According to the findings of the research, prospective teachers preferred verbal $(92 \%)$, note and $(80 \%)$ real life representations in defining the note values in general terms. On the other hand, geometrical and algebraic representations were preferred at lower rates. The mathematical expressions of the vast majority were found to be correct when the accuracy of representations chosen by the teacher candidates were analyzed. Problems experienced in relation to mathematical expressions in teaching note values include disproportionate fragmentation, modeling error, and algebraic error. On the other hand, representations used in the teaching of note values have generally been unsuccessful in musical expressions; the problems faced in articulation were determined as not (being able to) showing note values, incorrectly showing quarter note values and incorrectly defining note values. The accuracy rates of mathematical expressions are higher than those of musical expressions, regardless of the representation used (note, real life, geometric, verbal, algebraic). In addition, research findings show that prospective teachers who use four types of representation in the teaching of note values are more successful in mathematical and musical context than those who use two and three representations.
\end{abstract}

Keywords: music teaching, note values, teaching mathematics, multiple representations, integration

\section{Introduction}

Representation received increased attention when it was added as a new process standard in the National Council of Teachers of Mathematics' (NCTM) Principles and Standards for School Mathematics (2000). The ways in which mathematical ideas are represented is fundamental to how people can understand and use those ideas" (NCTM, 2000, p. 67). "A representation is a configuration that can represent something else in some manner" (Goldin, 2002, pp. 208).

Literature provides different classification of representations. Bruner (1966) found three distinct ways in which people represent the world: (a) through action, (b) through visual images, and (c) through words and language. Some researchers have reduced the three types to two categories (Clark \& Paivio, 1991; Marzano, 2004; Marzano, Pickering, \& Pollock, 2001) or included additional categories (Lesh, Landau, \& Hamilton, 1983). Moreover, dual coding theory maintains that there are two systems of representation (verbal and visual) that allow the brain to process and store information in memory (Clark \& Paivio, 1991). Lesh, Landau, and Hamilton (1983) found five kinds of representations that are useful for mathematical understanding: (a) real life experiences, (b) manipulative models, (c) pictures or diagrams, (d) spoken words, and (e) written symbols.

The use of different representations in teaching is emphasized by national and international programs. The National Council of Teachers of Mathematics (NCTM) expects teachers to encourage students to use multiple representations (NCTM, 2000). Mathematics teachers should arrange environments where students can present their forms of representation and discover relationships between different representations of a mathematical concept (NCTM, 2000; Smith, 2004). Mathematics curriculum of secondary school, which is being practiced in Turkey, requires from students to be able to express concepts with different forms of representation (MEB, 2013). In the primary education music program, the interdisciplinary approach was taken as a basis for teaching music and the necessity of ensuring 
conceptual integrity within each of the courses in vertical axis and inter-lecture in horizontal axis was sought.

The term integration literally means "to combine into a whole." Thus, when integrating curricula, the emphasis is on a comprehensive understanding of a "whole," rather than many unrelated parts (NCSBE 2003). Integrity is defined as a "collective aggregation of two equal groups" (Berke, 2009). This method known alternatively as integrated, interdisciplinary, blended, or collaborative teaching that combines ideas, terminology, or examples from multiple, unrelated subjects in ways that encourage a deeper understanding of the material—more than could be accomplished by presenting them separately. This type of teaching provides students with multiple access points where they can express or analyze the material and thereby enable them to construct their understanding of a topic appropriately in their own way of thinking (Overland, 2013).

Most teachers believe that music can enhance learning in other subjects such as math, science, arts, history and social studies (Giles \& Frego, 2004; Stroud, 1981; Wiggins \& Wiggins, 2008, Özgül, 2015) and have found a number of ways to integrate the arts in the classroom. It is considered for most of the educators that mathematics and music are logically associated. Mathematical qualities are inherent in music such as rhythm, tempo and melody. When the written sources of the two disciplines are examined, the use of clefs, quavers, staves and bar lines are the internationally-recognized symbols for music, whereas for mathematics it is numbers, signs of equality / inequality and algebraic notation (Smith, 1993). As a result of the strong relationships between mathematics and music, most activities have been proposed to help teachers integrate mathematics and music in the classroom (Fernandez, 1999; Greeley \& Offerman, 1998; Johnson \& Edelson, 2003; Stevens, Sharp \& Nelson, 2001). Embedding music activities naturally into children's engagements with mathematics and movement provides a way for children to simultaneously develop their logical/mathematical and musical/rhythmic intelligences (Shilling, 2002). According to Sherman (2015), music can be incorporated into most, if not all school subject matters. Music can help to teach math by counting, measuring, fractions and other mathematical applications can be put to music to help understand it better.

\section{Problem Status}

Prospective pre-school teachers take mandatory music education (1-2) during their undergraduate education. During the course of these lessons, rhythm, melody, texture, dynamics, music, and the process of making sense of these items has an important place. In this context, this study is only related to rhythm items and teaching of the same. Very different approaches are used in classroom environments to perceive rhythm items or note values. For example, According to Houlahan \& Tacka (2015), in the original Hungarian method for teaching rhythms, the teacher used word substitutions that were replaced by rhythm syllables such as Takadimi rhythm, Kodaly rhythm.

In the Turkish school music teaching, the values of full, half and quarter note values (), which are the rhythmic reflections of our speeches, are taken as basis. The rhythmic reflections of our language/speech are taken as basis, i.e. "words and language" are used as a means of representation, moving from our Native Language Turkish, such as school music based rhyme, counting, proverbs and songs (Karkın, 2004; Özgül 2014, 2016; Sun, 2002). As is the case with other disciplines related to education, in school music education practices, studies on teacher candidates stand out in their learning about how teacher candidates can teach a subject besides their own learning process. In this context, while trying to answer questions such as "How do they learn?" or "How can I teach better?" on the other hand, we try to determine the errors of learning process and the sources of these errors. In this context, when the studies conducted in the literature were examined, it was found that there was no study on "Preferential Representations" of teacher candidates in the process of learning the note values.

The literature has been used as a tool to understand the use of different representations in learning environments and to deepen understanding and learning (Adadan, 2006, 2013; Mayer, 2003; Sankey, Birch, \& Gardiner, 2010; Treagust, Chittleborough, \& Mamiala, 2003; Tsui \& Treagust, 2003; Wu \& Puntambekar, 2012), increase in interest and motivation levels sentence structure (Chen \& Fu, 2003, Prain \& Waldrip, 2006, 2010, Waldrip, Prain \& Carolan, 2010). Recent studies, however, indicate that the use of different representations helps overcome deficits in one representation by other representations and supports learning in this context (Ainsworth \& Van Labeke, 2004; Kaput, 1989; Prain \& Tytler, 2012; Van der Meij, \& De Jong, 2006). However, the skills that are at the focal point of conceptual learning are the ability to identify and express the same concept in different forms of representation, to choose the most appropriate representation from among the various representations, and to be aware of the advantages and disadvantages of the representations (Even, 1998). For these reasons, in recent years, researchers have a consensus on the need to develop and integrate different representations used for different needs in order to better understand the content (Kress, Jewitt, Ogborn, \& Tsatsarelis, 2001; Lemke, 2004; Norris \& Phillips, 2003).

The use of these representations in teaching has also been emphasized by standards developed at the institutional level (e.g., NCTM, 2000, MEB, 2013). Representations are important tools to develop reasoning, to increase communication and to continue thinking critically (Kilpatrick, Swafford, \& Findell, 2001). The American National Council of Teachers 
of Mathematics treats multiple representations as a process standard. In their respective documents, it is emphasized that students create, represent, compare and use different representations to develop and deepen their concept learning (NCTM, 2000).

Therefore, the study aims to determine the representations preferred by teacher candidates in the teaching of note values and to analyze and associate the representations preferred in mathematics and music context. As part of this purpose, the study looked for answers to the following questions:

1) How was the distribution of the representations that the teacher candidates preferred in the teaching of note values?

2) What are the accuracy values of preferred representation expressions in the context of mathematics and music disciplines, and what are the problems encountered in representing note values?

3) How are the mathematical and musical accuracy states of the representations related?

\section{Method}

In the study, "case study" method, one of the qualitative research designs, was used. The most essential feature of qualitative case study is the in-depth investigation of one or more cases (Ary, Jacobs, Razavieh and Sorensen, 2006; Creswell, 2009; Yıldırım \& Şimşek, 2011). The case that is studied in this study is examination of prospective teachers' ability to switch between multiple representations of note values and their preferences of representations.

\subsection{Sample}

The participants of the study constitute 113 prospective teachers who are studying in the third grade at pre-school teacher education program. In practice, 10 candidate teachers did not respond to the questionnaire. Therefore, those were excluded and 103 data were taken into consideration. A purposeful sampling method was used to select the participants. Criteria considered in the identification of participants were for them to have completed mathematics education in the second grade 4th semester and music education-1 in the 3rd and 5th semester and registered in music education- 2 course. The backgrounds of the students were gathered with a demographic questionnaire, in which the age, gender and experience of mathematics music lessons were studied. According to demographic survey results, of the 113 teacher candidates, $104(92 \%)$ are female and $09(8 \%)$ are male. Average age of prospective teachers is 21 . The experience of students in mathematics is based on the mathematics education course they have taken in the 2 nd grade of the 4th semester and the success average is calculated as 83.61 (range 0-100). On the other hand, prospective teachers' past experiences of music lessons were they took Music Education-1 course in 3rd grade 5th semester and the average of success is 79.16 .

\subsection{Data Collection Tool}

An open-ended questionnaire was used to collect the data of study. Open-ended surveys allowed participants to reflect their views in a natural and original way. The question included in the questionnaire is as follows. "Show examples of which representations you prefer with regards to teaching of full, half, and quarter note values". The questionnaire was prepared by the researchers and opinions were obtained from the relevant field experts. The questionnaire was administered in the test environment and sufficient additional time was given to the participants.

\subsection{Analysis of Data}

In the analysis of the data obtained from the questionnaire, content analysis technique and descriptive statistics were used. The data obtained were firstly analyzed in terms of the types of representation used in the teaching of note values. Specified types of representation were divided into subcategories within the context of relations between them. From there, a coding scheme was created (Table 1). In the next step, the accuracy states of the types of representations used by the students were analyzed in the context of music and mathematics disciplines. Mathematical and musical errors that teacher candidates made in the representation of note values were also determined at this stage.

The data were coded by four experts, two from music education and two from mathematics education. All experts have doctoral degrees in their respective fields. Percentage of correspondence between the codings was calculated as $94 \%$ for the mathematicians and $88 \%$ for the musicians according to the Miles and Huberman (1994) formula. Discussions were made on the items causing the dispute and a decision is reached.

\subsection{Ethical Situations}

In this study the participants were not harmed in any sense. During data collection, each student was provided with the same information and participants were asked to use their nicknames on their answer sheets. In addition, all participants voluntarily participated in the study. 


\section{Findings}

In this section, firstly, findings about the types of representation that teacher candidates preferred were presented according to research problems and then the accuracy of the expressions of these representations were analyzed in the context of mathematics and music disciplines.

\subsection{Teacher Candidates' Preferences of Representation Types}

Table 1 shows the breakdown of representations that teacher candidates preferred to teach the note values. The preferred representations in teaching are grouped under five headings: geometric representations, real life representations, algebraic representations, verbal representations and notational representations. Moreover, teacher candidates considerably preferred verbal $(92 \%)$, note $(80 \%)$, and real life representations $(72 \%)$. On the other hand, only $28 \%$ of the teacher candidates preferred geometric representations and $20 \%$ preferred algebraic representations for the representation of note values. However, square models were the most preferred among geometric representations $(22 \%)$, and more than half of the students in real life representations preferred the apple model in teaching of note values.

Table 1. The preferred representations in teaching of note values (\%)

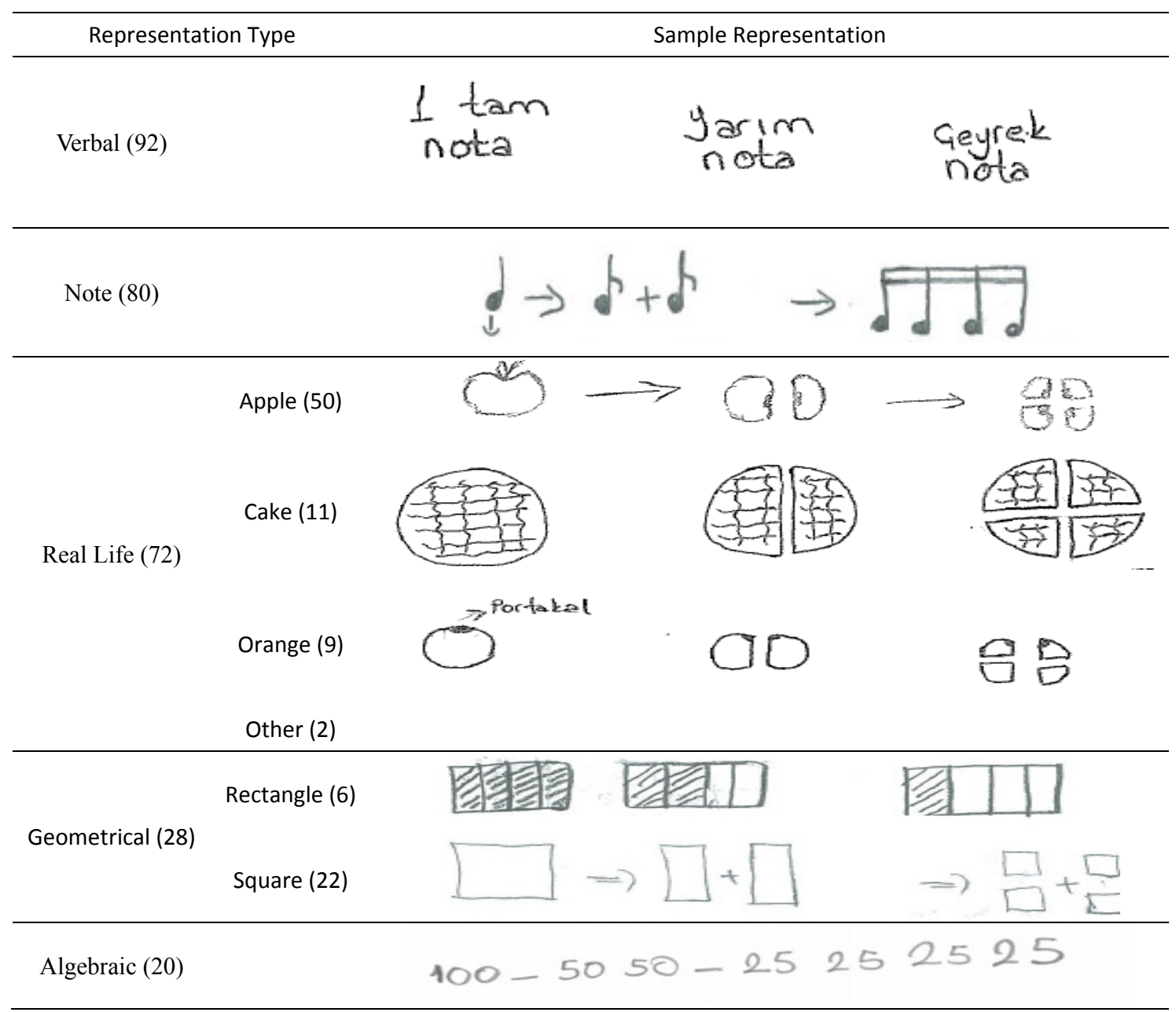

Note: Percentages are provided within parentheses.

\subsection{Accuracy of Representation Expressions in the Context of Mathematics and Music Disciplines}

The findings in this section examine the accuracy of mathematical and musical expressions of preferred representations in note values and the problems encountered in both contexts.

\subsubsection{Accuracy of Mathematical Expressions of Representations}

The accuracy of the mathematical expressions used by the prospective teachers in teaching the note values are given in Table 2. According to the table, the accuracy of the mathematical expressions of the representations are seen to be between the range of $78 \%-100 \%$ and have a high success rate. When the accuracy states are analyzed according to 
representation types, despite the standing out of students' higher success rate in algebraic, note and geometric representations, their success in the representation types including note, verbal and real life situations are drawing attention when the frequency of use is considered.

Table 2. Accuracy of mathematical expressions of representations

\begin{tabular}{cccc}
\hline \multicolumn{2}{c}{ Model Type } & $\begin{array}{c}\text { Number of } \\
\text { Representations }\end{array}$ & Accuracy Rate \\
\hline \multirow{3}{*}{ Geometrical } & Rectangle & 6 & 100 \\
& Square & 23 & 83 \\
& Total & $\mathbf{2 9}$ & $\mathbf{8 6}$ \\
\hline \multirow{3}{*}{ Real Life } & Apple & 52 & 81 \\
& Cake & 11 & 91 \\
& Orange & 9 & 78 \\
Algebraic & Other & 2 & 100 \\
Verbal & Total & $\mathbf{7 3}$ & $\mathbf{8 2}$ \\
Note & & 21 & 95 \\
\hline
\end{tabular}

\subsubsection{Problems Encountered with Mathematical Articulation}

The mathematical problems encountered in the models used by the teacher candidates in teaching the note values are given in Table 3. According to the table, disproportionate fragmentation $(n=14)$ is the leading problem of prospective teachers encounter in mathematical expressions. For example, a prospective teacher (T11) used a square model to teach the values of notes. When this teacher showed the complete note with a full square, (s)he used two pieces of the same size as the square used in the representation of the full notation to represent the half note, and four pieces of the same size for the quarter note representation. In this context, when passing from the full note to the other notes, the full square does not break up at the appropriate rate. The most common problem after disproportionate fragmentation were the algebraic mistakes. An algebraic mistake, for example, T75 expresses a full note with number 100, half note with number 50, while a quarter note with 15 and is mistaken.

Table 3. Problems encountered with mathematical articulation

\begin{tabular}{|c|c|c|}
\hline Errors encountered & $\mathrm{n}$ & Sample \\
\hline Disproportional Fragmentation & 14 & 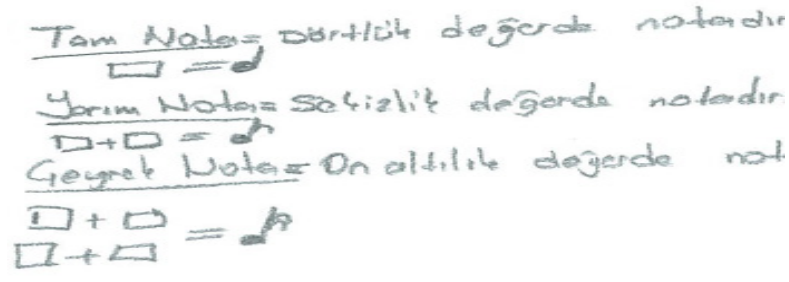 \\
\hline Algebraic mistake & 4 & 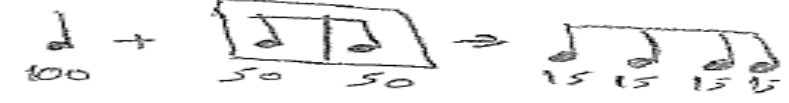 \\
\hline Total & 18 & \\
\hline
\end{tabular}

\subsubsection{Accuracy of Musical Expressions}

The accuracy of the musical expressions of the representations used by the teacher candidates in teaching the note values are given in Table 4. Contrary to the accuracy values in mathematical expressions, it is seen that the prospective teachers show lower success $(41 \%-67 \%)$ in musical expressions of representations they prefer in teaching the note values. When the accuracy cases were analyzed according to types of representation, the prospective teachers had higher success in algebraic, note and geometric representations. When the frequency of use is taken into account, it is noteworthy that the majority of the teachers in the types of representation, including verbal and real life situations, fail. 
Prospective teachers who especially use orange and cake representations in their real life models mostly gave musical expressions of these representations more accurately, while mistakes were found in the musical expressions of apple models used by the majority of students. This indicates that mistakes in the musical expressions of real life representations originate from teacher candidates using the apple model.

Table 4. Accuracy of the musical expressions of the note representations

\begin{tabular}{llcc}
\hline & Model Type & $\begin{array}{c}\text { Number of } \\
\text { Representations }\end{array}$ & Accuracy Rate \% \\
\hline Geometrical & Rectangle & 6 & 67 \\
& Square & 23 & 65 \\
& Total & $\mathbf{2 9}$ & $\mathbf{6 6}$ \\
\hline Real Life & Apple & 52 & 31 \\
& Cake & 11 & 64 \\
& Orange & 9 & 78 \\
& Other & 2 & 0 \\
& Total & $\mathbf{7 4}$ & $\mathbf{4 1}$ \\
\hline Algebraic & & 21 & 67 \\
\hline Verbal & & 95 & 44 \\
\hline Note & & 82 & 57 \\
\hline
\end{tabular}

\subsubsection{Problems Encountered in Musical Articulation of Models}

The problems encountered in the musical expressions of the models used by the teacher candidates in teaching the note values are given in Table 5. According to the table, the problems encountered by the students in musical expressions were collected in two groups as originating from presentation of note values $(\mathrm{n}=43)$ and originating from definition of note values ( $\mathrm{n}=11)$. The most common problem with note presentation is that the note values are (not able to be) shown. As in the example given in Table 5, some students did not (were not able to) write the musical notation of the notes they gave by model and verbal expression. Again, the value of the quarter note stands out by the mistakes made in the presentation. For example, T18 correctly used the apple model in the expression of the note values, but he made a mistake in the musical expression of this model and the display of the quarter note. The problem that teacher candidates experienced in definition of note values were incorrect identification of the note values $(n=11)$. As in the example given in the table, while the teacher candidates were successful in model representation and verbal expression of note values, they failed to write musical expressions of their own values. 
Table 5. Problems encountered in musical expressions

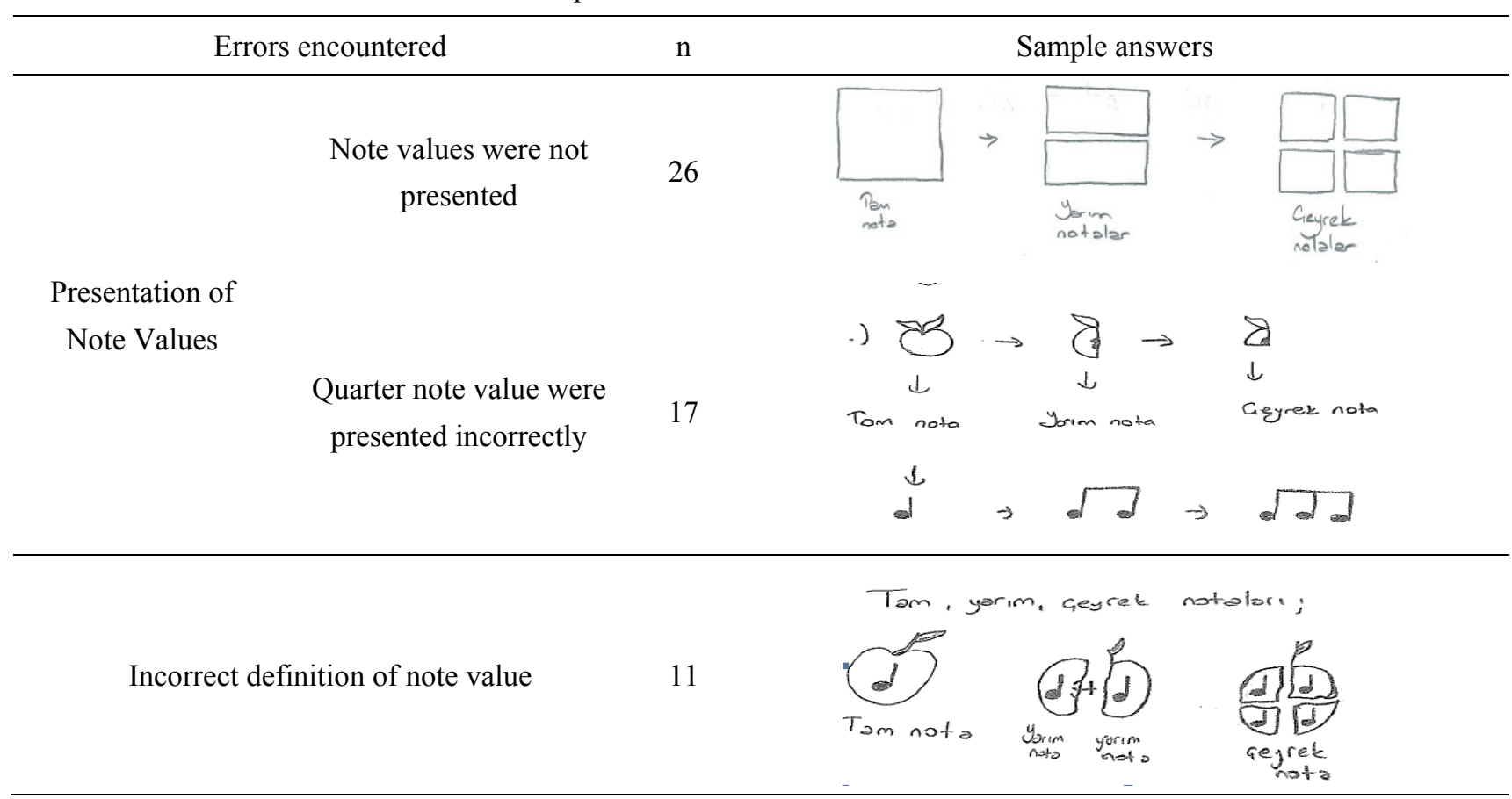

Table 6 compares the accuracy of the mathematical and musical expressions in the representations used by the students. Accordingly, majority of students with correct and incorrect musical expressions also have correct mathematical expressions. On the other hand, while musical expressions of more than half $(n=45)$ of those with correct mathematical expression $(n=86)$ are correct, 13 of the 17 people whose mathematical expression are incorrect have incorrect musical expressions. From here, it can be inferred that the musical errors are more decisive in the mistakes that students made in the representation of the notes.

Table 6. Comparative analysis of mathematical and musical expressions

\begin{tabular}{ccc}
\hline & \multicolumn{2}{c}{ Musical Expression } \\
\hline Mathematical Expression & D & Y \\
D & 45 & 41 \\
Y & 4 & 13 \\
\hline
\end{tabular}

\subsubsection{Accuracy of Mathematical and Musical Expressions Used More Than Once}

Table 7 shows the simultaneous use cases of multiple representations and the successes of mathematical and musical expressions of these representations. According to the table, regardless of the number of representations used, the mathematical accuracy rates of the representations used by the students in note values were found to be higher than musical accuracy rates. While the majority of the students $(n=63)$ used the three representations at the same time, only 16 students used the four representations simultaneously. However, no prospective teacher used all the representations together. Most of the musical expressions are correct while the mathematical expressions of the representations that the students who use the four different representations at the same time are correct. On the other hand, it is noteworthy that the mathematical accuracy of the representations of students who use two or three representations is lower than that of the students who use all representations but it is around $50 \%$ in the musical expressions of the students who use the three representations and $25 \%$ of the students who use the two representatives together. 
Table 7. Representations and accuracy rates used at the same time

\begin{tabular}{cccc}
\hline & & \multicolumn{2}{c}{ Accuracy Rate } \\
\hline Number of Representations & Representation Types & Music & Mathematic \\
& NGCS & 67 & 100 \\
FOUR & NGySC & 69 & 100 \\
& Common (16) & $\mathbf{6 9}$ & $\mathbf{1 0 0}$ \\
& NGC & 100 & 100 \\
& NGS & 63 & 79 \\
THREE & NGyC & 50 & 100 \\
& NGyS & 44 & 85 \\
& GySC & 50 & 50 \\
& Common (63) & $\mathbf{5 1}$ & $\mathbf{8 3}$ \\
& NG & 100 & 100 \\
& GS & 33 & 100 \\
& NGy & 50 & 50 \\
& SGy & 0 & 69 \\
& Common (24) & $\mathbf{2 5}$ & $\mathbf{7 5}$ \\
\hline
\end{tabular}

Note: N: Note representation; G: geometric representation; S: verbal representation; C: algebraic representation; Gy: real life representation. Number of representations used are given in parenthesis.

\section{Conclusion}

In this study, an evaluation of representations that prospective teachers prefer in the teaching of note values was performed in the context of mathematics and music. The results of the research are limited by the participants and the data collection tools used.

According to the results of the research, teacher candidates preferred verbal, note, real life representations among the specified representations (note, verbal, real life, geometric and algebraic representations). It is thought that it is natural for them to use their note representations at a high level because the subject is to express the values of the notes. The reasons for using real life representations more are that the practices in textbooks, the approaches used in classroom teaching, and especially the activities related to fractions, may be due to the fact that teachers have included such models. On the other hand, while the square model in the geometrical representations stands out, more than half of the students preferred the apple model in the real life representations, in teaching of note values. In the teaching of full, half, and quarter note values, it can be argued that the use of apple models from real life representations is a traditional approach from mathematics courses and music lessons in the teaching of fractions in primary education (Çetin, 2011). However, the students correctly used the apple model in the expression of the note values, but made a mistake in the musical expression and the quarter note presentation of this model. This finding suggests that the apple model is not a suitable model for teaching the note values.

Prospective teachers also made disproportionate fragmentation in their models and algebraic mistakes in mathematical articulation. This mistake might have been caused because of their misconceptions in the concept of fractions. Many students appear to see fractions as two unrelated whole numbers (Hart, 1989). Even questions using pre-partitioned regions designed to ascertain students' regional "parts of a whole" understanding may be subject to whole number interpretations (Gould, Outhred, \& Mitchelmore, 2006). Some students focus on the "number of pieces" named by a fraction and others the "number of equal pieces" named, without addressing the relationship between the area of the parts compared to the area of the whole region. One implication from here is the need to reduce the dependence on pre-partitioned shapes in teaching and assessing fractions (Gould, Outhred, \& Mitchelmore, 2006).

In musical articulation, candidate teachers experienced a two-dimensional problem in the way that note values are shown and defined. The most common problem with the presentation of note values is that the note values are not shown at all and the quarter note values are presented incorrectly. Therefore, it can be suggested that the students cannot carry out the interpretation related to note values well. Perceptions of candidate teachers in Turkey regarding note reading is discussed in several studies. In the data obtained by using (observation) form on note-reading abilities of prospective teachers prepared by researchers, the students are found to be failing regarding recognizing, reading 
accurately and rhythmically, practicing, carrying out beats smoothly by hand the note values in selected works from level-appropriate school music samples (Yünlü \& Sağlam, 2004; Afacan, 2007; Arapgirlioğlu and Karagöz, 2010; Kurtaslan \& Koca 2013).

In order to be able to perceive most musical concepts, concrete experiences are needed. Children or those who learn a new a subject need many experiments structured with concrete models so that they can work meaningfully with abstract symbols. It may be thought that models such as cake, apples, oranges are suitable for real life models in teaching half and quarter values in mathematics lessons but it can be argued that full, half and quarter note values are not a good model in the process of perception of real life models. Therefore, the square and rectangle model of the geometric models is a more effective model for the perception and interpretation of the note values. Because the display of full, half, and quarter note values in these two models can be matched clearly, it is unlikely to say the same for different models such as geometric models, circle, triangle etc. (Figure 1). Beth Ann Miller (2012) states in her work "Rhythmic Instruction from Square One" that students memorize the knowledge of full, half, and quarter values notes without realizing the truth, and that the number of measures is challenged by the relation between notes and "time signature". In music lessons, associating full, half, and quarter note values with the square model will help students to learn more easily and deeply.
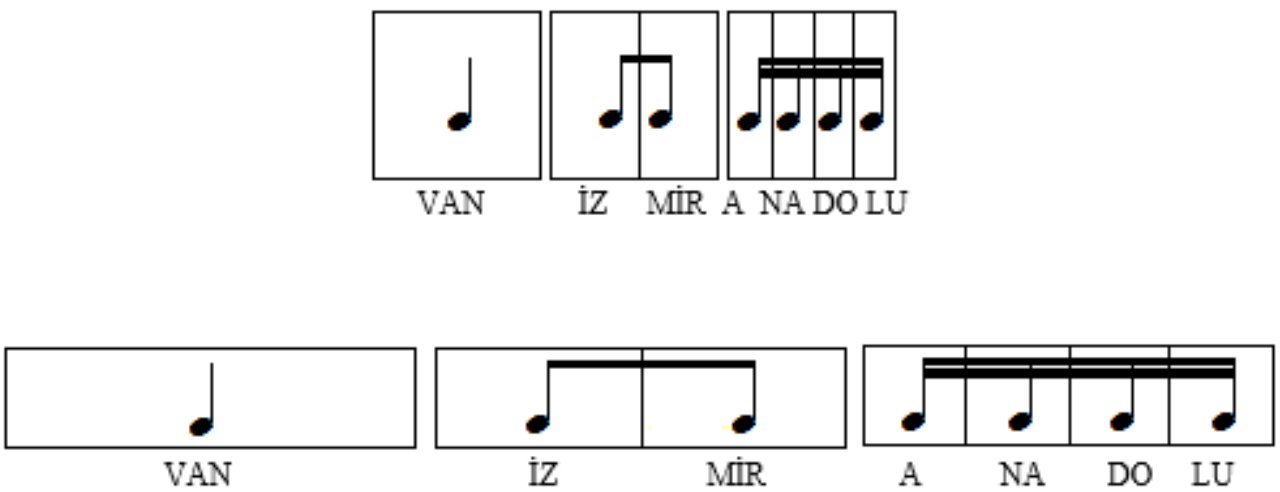

Figure 1. Relation of full, half and quarter value of notes with verbal and geometric model

Considering the number of use of representations of the students, they did not use all the representations, i.e. 5 representations together. It is true that most of the musical expressions are correct while the mathematical expressions of the representations that the students using the four different representations use in their musical scores are all correct. On the other hand, it is important that the mathematical accuracy of the representations of the students who use two or three representations is inadequate/very poor for the students who use three representations, while the performances of the students who use three representations are lower than those who use all representations. This is consistent with the studied conducted. Studies show that the use of different representations helps overcoming deficits in one representation by other representations and in this context, supports learning (Ainsworth \& Van Labeke, 2004; Kaput, 1989; Prain \& Tytler, 2012; Van der Meij, \& De Jong, 2006). For this reason, in recent years, researchers have come to a consensus on the need to develop and integrate different representations used for different needs so that their content can be understood better.

In order to investigate more deeply the findings of teaching note vales, educators working at different levels of learning should be directed to similar studies. Thus, he/she will bring new examples/solutions/suggestions to the inefficient/inadequate learning and teaching approaches that have become divided with the traditional understanding in the literature.

\section{Note}

This work was presented at the Eğitimde Değişim Konferansları in an oral presentation, İstanbul: 10-11 Aralık 2016, MEF Üniversitesi Ayazağa, İstanbul/Turkey. 


\section{References}

Adadan, E. (2006). Promoting high school students' conceptual understandings of the particulate nature of matter through multiple representations. Unpublished Doctoral Dissertation, The Ohio State University, Ohio.

Adadan, E. (2013). Using multiple representations to promote grade 11 students'scientific understanding of the particle theory of matter. Research in Science Education, 43, 1079-1105. https://doi.org/10.1007/s11165-012-9299-9

Afacan, Ş. (2007). Examining Elementary Education Pre-Service Teachers Self-Efficacy Beliefs. Paper Presented at the 16th National Educational Sciences Congress, Tokat, Turkey.

Ainsworth, S., \& Van Labeke, N. (2004). Multiple forms of dynamic representation. Learning and Instruction, 14(3), 241-255. https://doi.org/10.1016/j.learninstruc.2004.06.002

Arapgirlioğlu, H., \& Karagöz, B. (2011). The Status and Evaluation of Music Education in the Process of Classroom Teaching. E-Journal of New World Sciences Academy, 6(1), 183-196.

Ary, D., Cheser, J. L., Razavieh, A., \& Sorensen, C. (2006). Introduction to research in education (7th ed.). Belmont, CA: Thomson/Wadsworth.

Berke, M. K. (2000). Curriculum integration: A two-way street. General Music Today, 14(1), 9-12. https://doi.org/10.1177/104837130001400104

Çetin, G. Ç. (2011). Etkinliklerle Müzik Öğretimi, Ankara: Kök Yayıncılık.

Chen, G., \& Fu, X. (2003). Effects of multimodal information on learning performance and judgment of learning. Journal of Educational Computing Research, 29(3), 349-362. https://doi.org/10.2190/J54F-B24D-THN7-H9PH

Clark, J. M., \& Paivio, A. (1991). Dual coding theory and education. Educational Psychology Review, 3(3), 149-210. https://doi.org/10.1007/BF01320076

Creswell, J. W. (2009). Research Design: Qualitative, Quantitative, and Mixed Methods Approaches. 3rd Edition. Los Angeles: Sage Publications, Inc. 2009.

Fernandez, M. (1999). Making music with mathematics. The Mathematics Teacher, 92(2), 90-92.

Giles, A. M., \& Frego, R. J. D. (2004). An Inventory of Music Activities Used by Elementary Classroom Teachers. Update: The Applications of Research in Music Education, 22, 13-22. https://doi.org/10.1177/87551233040220020103

Goldin, G. A. (2002). Representation in mathematical learning and problem solving. In L. D. English (Ed.), Handbook of international research in mathematics education (pp. 197-218). Mahwah, NJ: Lawrence Erlbaum Associates, Publishers.

Gould, P., Outhred, L., \& Mitchelmore, M. (2006). One-third is three-quarters of one-half. Paper presented at the annual meeting of the Mathematics Education Research Group of Australia, Australia.

Greeley, N., \& Offerman, T. (1998). Now and then: Dancing in time and space. Mathematics Teaching in the Middle School, 4(3), 192-194.

Hart, K. (1988). Ratio and proportion. In J. Hiebert \& M. J. Behr (Eds.), Number concepts and operations in the middle grades (pp. 198-219). Hillsdale, NJ: Lawrence Erlbaum Associates.

Houlahan, M., \&Tacka, P. (2015). Kodaly Today A Cognitive Approach to Elementary Music Education second edition, Newyork, NY: Oxford University Press.

Johnson, G., \& Edelson, R. (2003). Integrating music and mathematics in the elementary classroom. Teaching Children Mathematics, 9(8), 474-479.

Kaput, J. J. (1989). Linking representations in the symbol systems of algebra. In S. Wagner \& C. Kieran (Eds). Research issues in the learning and teaching of algebra (pp. 167-194). Hillsdale, NJ: LEA.

Karkın, K. (2004). Solfej Eğitimi 1, Anklara: Elit Yayıncılık,

Kilpatrick, J., Swafford, J., \& Findell, B. (Eds.). (2001). Adding it up: Helping children learn mathematics. Washington, DC: National Academy Press.

Kress, G., Jewitt, C., Ogborn, J., \& Tsatsarelis, C. (2001). Multimodal teaching and learning: The rhetorics of the science classroom. London: Continuum

Kurtaslan, H., \& Koca, Ş. (2013). Prospective Primary School Teachers' Perspectives of Recorder Education in Music Education Courses. Journal of Research in Education and Teaching, 2(4), 145-151. 
Lemke, J. (2004). The literacies of science. In E. W. Saul (Ed.), Crossing borders in literacy and science instruction: Perspectives on theory and practice (pp. 33-47). Newark: International Reading Association/National Science Teachers Association. https://doi.org/10.1598/0872075192.2

Lesh, R., Landau, M., \& Hamilton, E. (1983). Conceptual models in applied mathematical problem solving research. In R. Lesh \& M. Landau (Eds.), Acquisition of mathematics concepts and kprocesses (pp. 263-343). New York: Academic Press.

Marzano, R. J. (2004). Building background knowledge for academic achievement: Research on what works in schools. Alexandria, VA: Association for Supervision and Curriculum Development.

Marzano, R. J., Pickering, D. J., \& Pollock, J. E. (2001). Classroom instruction that works: Research-based strategies for increasing student achievement. Alexandria, VA: Association for Supervision and Curriculum Development.

Mayer, R. (2003). The promise of multimedia learning using the same instructional design methods across different media. Learning and Instruction, 13, 125-139. https://doi.org/10.1016/S0959-4752(02)00016-6

MEB. (2006). Primary School Music Teaching Program and Handbook. Ankara: Milli Eğitim Basımevi.

MEB. (2013). Ortaokul matematik dersi öğretim programı. Ankara.

Miles, M. B., \& Huberman, A. M. (1994). Qualitative data analysis: An expanded sourcebook. Thousand Oaks: Sage Publications.

Miller, B. A. (2012). Rhythmic Instruction From Square One: A Constructivist Teacher and Her Metronome, General Music Today 26, 19-27. https://doi.org/10.1177/1048371312438134

NCTM National Council of Teachers of Mathematics. (2000). Principles and standards for school mathematics. Reston, VA: Author.

Norris, S., \& Phillips, L. (2003). How literacy in its fundamental sense is central to scientific literacy. Science Education, 87, 224-240. https://doi.org/10.1002/sce.10066

North Carolina State Board of Education (NCSBE). (2003). Arts Education Teacher Handbook: Music 130.

Overland, C. T. (2013). Integrated arts teaching: What does it mean for music education? Music Educators Journal, 100, 31-37. https://doi.org/10.1177/0027432113497762

Özgül, İ. (2014). Music Education and Teaching: Theories, Solfeggio, Songs, Approaches. 7th ed. Ankara: Pegem Akademi Yayınları.

Özgül, İ. (2015). Changing paradigms in general music education. Educational Research and Reviews, 10(8), 1293-1299. DOI: 10.5897/ERR2015.2103

Özgül, İ. (2016). Integration in general music education, Conference for Academic Disciplines (Cambridge: 23-27 May 2016). ABD: Harvard University Harvard Medical School, Conference of the International Journal of Arts \& Sciences (IJAS), 9(2), 53-60. http://www.universitypublications.net/proceedings/0902/pdf/H6V309.pdf

Prain, V., \& Waldrip, B. (2010). Representing Science Literacies: An Introduction. Research in Science Education, 40, 1-3. https://doi.org/10.1007/s11165-009-9153-x

Sankey, M., Birch, D., \& Gardiner, M. (2010). Engaging students through multimodal learning environments: The journey continues. In C.H. Steel, M.J. Keppell, P. Gerbic \& S. Housego (Eds.), Curriculum, technology \& transformation for an unknown future. Proceedings ascilite Sydney 2010, (pp.852-863).

Shilling, W. (2002). Mathematics, music and movement: Exploring concepts and connections. Early Childhood Education Journal, 29(3), 179-184. https://doi.org/10.1023/A:1014536625850

Smith, S. P. (2004). Representation in school mathematics: Children's representations of problems. In J. Kilpatrick (Ed.), A Research Companion to Principles and Standards for School Mathematics (pp. 263-274), Reston, VA: NCTM, Inc.

Stevens, A., Sharp, J., \& Nelson, B. (2001). The intersection of two unlikely worlds: Ratios and drums, Teaching Children Mathematics, 7(6), 376-377.

Stroud, B. S. (1981). A Study of the General Classroom Music Programs in the Public Elementary School of the Tidewater Region of Virginia. PhD diss., University of Illinois at Urbana-Champaign.

Sun, M., \& Seyrek, H. (2002). Okul öncesi eğitiminde müzik. İzmir: Mey Yayınları.

Treagust, D., Chittelborough, G., \& Mamiala, T. (2003). Students' understanding of the role of scientific models in learning science. International Journal of Science Education, 24(4), 357-368. 
https://doi.org/10.1080/09500690110066485

Tsui, C. Y., \& Treagust, D. F. (2003). Genetics reasoning with multiple external representations. Research in Science Education, 33(1), 111-135. https://doi.org/10.1023/A:1023685706290

Van der Meij, J., \& De Jong, T. (2006). Supporting students' learning with multiple representations in a dynamic simulation-based learning environment. Learning and Instruction, 16(3), 199-212. https://doi.org/10.1016/j.learninstruc.2006.03.007

Waldrip, B., Prain, V., \& Carolan, J. (2010). Using multi-modal representations to improve learning in junior secondary science. Research in Science Education, 40(1), 65-80. https://doi.org/10.1007/s11165-009-9157-6

Wiggins, R. A., \&Wiggins, J. (2008). Primary Music Education in the Absence of Specialists. International Journal of Education and the Arts, 9(12), 1-26.

Wu, H. K., \& Puntambekar, S. (2012). Pedagogical affordances of multiple external representations in scientific processes. Journal of Science and Educational Technology, 21, 754-767. https://doi.org/10.1007/s10956-011-9363-7

Yıldırım, A., \& Şimşek, H. (2011). Sosyal Bilimlerde Nitel Araştırma Yöntemleri. (8.baskı). Ankara: Seçkin Yayıncılık.

Yünlü, F., \& Sağlam, M. (2004). Grade Teachers' Opinion Regarding Music Class Difficulties in the Course Contents and Educational Needs. Eğitim Bilimleri ve Uygulama Dergisi, 3(6), 211-226.

\section{Copyrights}

Copyright for this article is retained by the author(s), with first publication rights granted to the journal.

This is an open-access article distributed under the terms and conditions of the Creative Commons Attribution license which permits unrestricted use, distribution, and reproduction in any medium, provided the original work is properly cited. 